The Emancipation of Writing 
STUDIES ON THE HISTORY OF SOCIETY AND CULTURE

Victoria E. Bonnell and Lynn Hunt, Editors 


\title{
The Emancipation of Writing
}

German Civil Society in the Making, 1790s-1820s

\author{
IAN F. MCNEELY
}

University of California Press

BERKELEY LOS ANGELES LONDON 
University of California Press

Berkeley and Los Angeles, California

University of California Press, Ltd.

London, England

(C) 2003 by the Regents of the University of California

Library of Congress Cataloging-in-Publication Data

McNeely, Ian F., 1971-

The emancipation of writing : German civil society in the making, 1790s-1820s / Ian F. McNeely.

p. $\mathrm{cm}$.

Includes bibliographical references and index.

ISBN 0-520-23330-1 (Cloth : alk. paper)

1. Bureaucracy-Germany-History. 2. Written CommunicationGermany-History. 3. Civil society-Germany-History. I. Title.

JN3221.M37 2002

300'.943'09033-dc21

2002002314

Manufactured in the United States of America

$\begin{array}{lllllllll}10 & 09 & 08 & 07 & 06 & 05 & 04 & 03 & 02\end{array}$

$\begin{array}{llllllllll}12 & 11 & 10 & 9 & 8 & 7 & 6 & 5 & 4 & 3\end{array}$

The paper used in this publication is both acid-free and totally chlorinefree (TCF). It meets the minimum requirements of ANSI/NISO Z39.481992 (R 1997) (Permanence of Paper). @) 
To my parents, G. F. and Sharon McNeely, and my wife, Lisa Wolverton 
This page intentionally left blank 